\title{
Rancang Bangun Multimedia Pembelajaran Interaktif Mata Pelajaran Ipa Terpadu Untuk Siswa Smpn 5 Kota Serang
}

Ahmad Fatoni $^{1}$, Penti Dewi Kuraesin ${ }^{2}$

Program Studi Sistem Informasi - Universitas Serang Raya

Serang -Indonesia

${ }^{1}$ ahmadfatoni101@gmail.com

${ }^{2}$ pentidewikuraesin@gmail.com

\begin{abstract}
Abstrak. Multimedia pembelajaran interaktif merupakan komponen sistem penyampaian pengajaran yang dapat digunakan dalam mendukung proses pembelajaran. Pengembangan media interaktif dilandasi oleh persepsi bahwa pembelajaran akan berlangsung dengan baik, efektif, dan menyenangkan jika didukung oleh media pembelajaran yang dapat menarik minat dan perhatian siswa. Apalagi saat ini penggunaan media pembelajaran berbasis Teknologi Informasi dan Komunikasi merupakan suatu keharusan. Berdasarkan UU Nomor14/2005 tentang Guru dan Dosen telah diputuskan bahwa "setiap guru harus dapat memanfaatkan teknologi informasi dan komunikasi untuk kepentingan penyelenggaraan kegiatan pengembangan yang mendidik. Metode penelitian yang digunakan oleh peneliti menggunakan metode pengembangan multimedia. Dalam pengembangan metode multimedia terdapat beberapa tahapan yaitu konsep, perancangan, pengumpulan bahan, pembuatan dan pengujian.

Hasil akhir dari penelitian ini berupa aplikasi Multimedia Pembelajaran Interaktif Mata Pelajaran IPA Terpadu untuk Siswa SMPN 5 Kota Serang yang berisi 6 tampilan yaitu terdiri dari tampilan awal, tampilan apersepsi, tampilan SK/KD, tampilan indikator, tampilan materi, tampilan simulasi dan tampilan evaluasi.
\end{abstract}

Kata Kunci : MediaPembelajaran Interaktif, simulasi, evaluasi.

\section{I.PENDAHULUAN}

Salah satu faktor yang sangat menentukan proses pembelajaran diantaranya adalah penggunaan media pembelajaran di dalam proses pembelajaran. Tetapi fakta di lapangan memperlihatkan kenyataan sebaliknya masih banyak guru yang malas menggunakan media pembelajaran untuk menunjang keberhasilan proses pembelajaran.Alasan guru tidak menggunakan media pada pembelajaran, sistem penyampaian pengajaran yang dapat digunakan dalam mendukung Multimedia pembelajaran interaktif merupakan komponen proses pembelajaran Pengembangan media interaktif dilandasi oleh persepsi bahwa pembelajaran akan berlangsung dengan baik, efektif, dan menyenangkan jika didukung oleh media pembelajaran yang dapat menarik minat dan perhatian siswa Metode pembelajaran dengan menggunakan perangkat komputer Pengembangan aplikasi multimedia interaktif dengan model penggabungan foto, audio dan video merupakan suatu bentuk aplikasi multimedia pembelajaran interaktif didalamnya terdapat campuran antara teks, gambar, audio, dan video (dan beberapa media lainnya) yang digabungkan dengan interaksi dari user.

\section{A.Tutorial}

Interaktif yang dalam penyampaian materinyaFormat sajian ini merupakan multimedia pembelajaran yang tampil selalu berbeda, atau paling tidak dalam kombinasi yang berbeda.sehingga setiap kali digunakan soal atau pertanyaan.dilakukan secara tutorial, sebagaimana layaknya tutorial yang dilakukan oleh guru dan atau instruktur. Informasi yang berisi suatu konsep disajikan dengan teks, gambar, baik diam atau bergerak dan grafik. Pada saat yang tepat, yaitu ketika dianggap bahwa pengguna telah membaca, menginterpretasikan dan menyerap konsep itu, diajukan serangkaian pertanyaan atau tugas. Jika jawaban atau respons siswa benar, kemudian dilanjutkan dengan materi berikutnya. Jika jawaban atau respons siswa salah, maka siswa harus mengulang memahami konsep tersebut secara keseluruhan ataupun pada bagian-bagian tertentu saja (remedial). Kemudian pada bagian akhir biasanya akan diberikan serangkaian pertanyaan yang merupakan tes untuk mengukur tingkat pemahaman siswa atas konsep atau materi yang disampaikan.

\section{B. Drill dan Practice}

Format ini dimaksudkan untuk melatih siswa sehingga memiliki kemahiran dalam suatu keterampilan atau memperkuat penguasaan suatu pembelajaran

\section{C.Simulasi}

Multimedia pembelajaran interaktif dengan formatini mencoba menyamai proses dinamis yang terjadi di dunia nyata, Pada dasarnya format ini mencoba memberikan pengalaman masalah dunia nyata yang biasanya berhubungan dengan suatu resiko.

\section{Adobe Flash CS6}

merupakan penyempurnaan dari jenis jenis Adobe Flash sebelumnya yang merupakan software yang dirancang untuk membuat animasi berbasis vektor dengan hasil yang mempunyai ukuran yang kecil. Awalnya software ini memang diarahkan untuk membuat animasi atau aplikasi berbasis internet (online). Tetapi pada perkembangannya banyak digunakan untuk membuat animasi atau aplikasi yang bukan berbasis internet (offline),

Tampilan awal Adobe Flash CS6

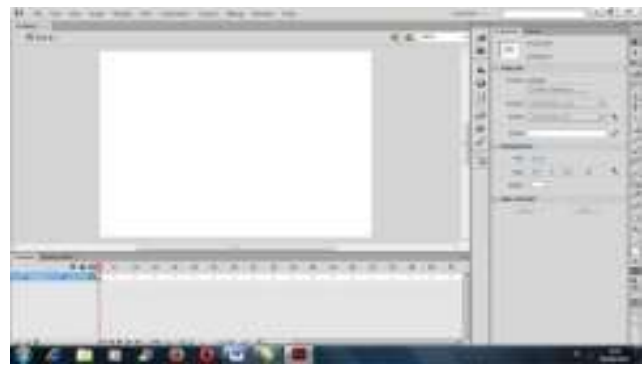


Gambar 1. Tampilan awal Adobe Flash CS6

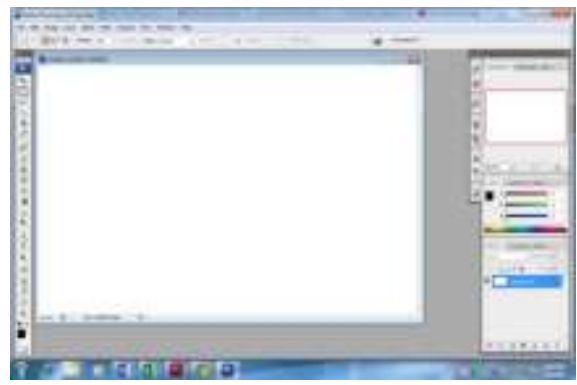

Gambar 2. Tampilan awal Adobe Flash CS6

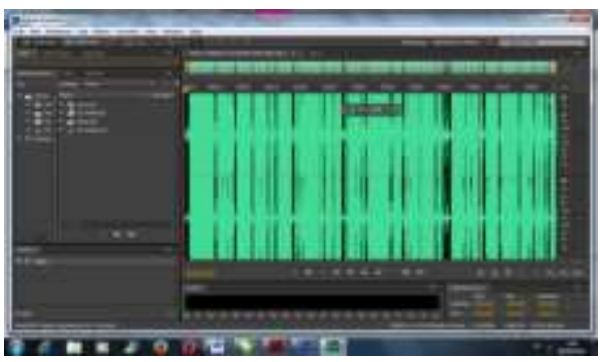

Gambar 3. Tampilan awal Adobe Flash CS6

\section{E.Windows Movie Maker 6.0}

Program Window Movie Maker 6.0 merupakan program yang sangat popular di dalam dunia editing film. Windows movie Maker adalah program editing film yang sangat mudah penggunaannya

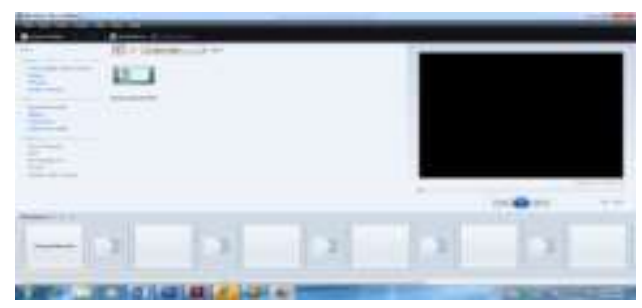

Gambar 1. Window Movie Maker 6.0

\section{ANALISA DAN PERANCANGAN}

Tahapan tahapan perancangan dan pembangunan Multimedia Pembelajaran Interaktif Mata Pelajaran IPA Terpadu untuk Siswa SMPN 5 Kota Serang ini dapat digambarkan sebagai berikut:

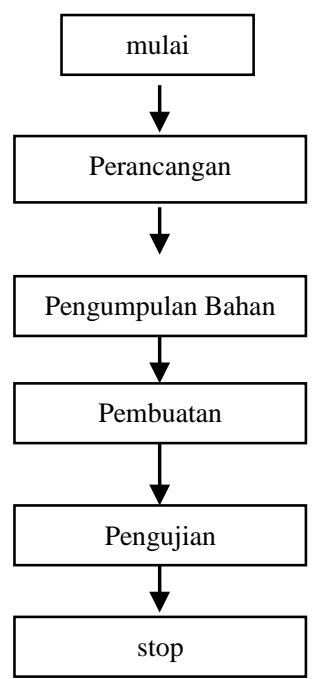

\section{A. Tampilan Analisa Data}

Data yang diperlukan untuk merancang dan membangun Multimedia

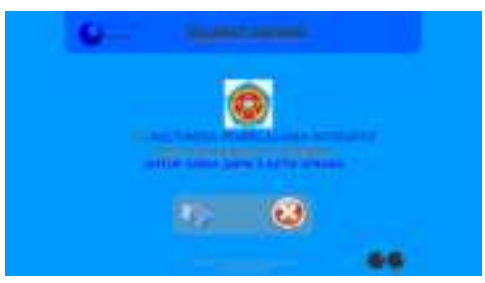

Gambar 1. Tampilan awal produk

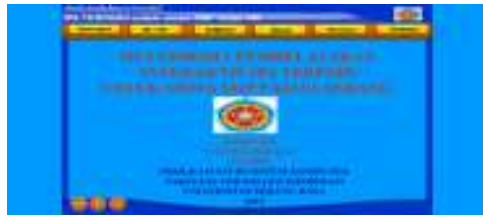

Gambar 2. Tampilan multimedia pembelajaran interaktif

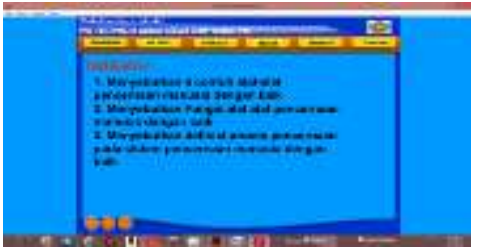

Gambar 3. Tampilan Indikator

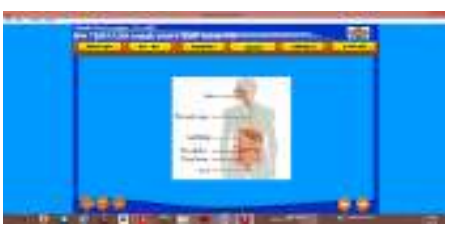




\section{Gambar 4. Tampilan Materi Pembelajaran}

\section{IV.HASIL DAN PEMBAHASAN}

\section{A.Tampilan Awal}

Tampilan awal terdiri dari animasi nama peneliti dan jurusan, ucapan selamat datang, logo Unsera, judul aplikasi, tombol masuk dan keluar, serta hak cipta dan tahun pembuatan

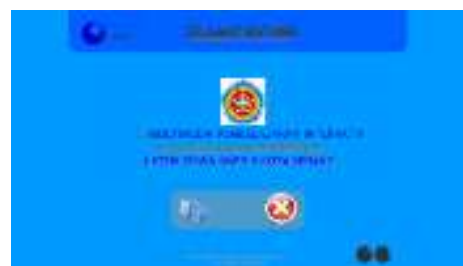

Gambar 1. Tampilan Awal Produk

\section{B.Tampilan Apersepsi}

Apersepsi adalah tes awal yang dilakukan untuk mengetahui sejauh mana pengetahuan siswa tentang materi yang akan dipelajari.

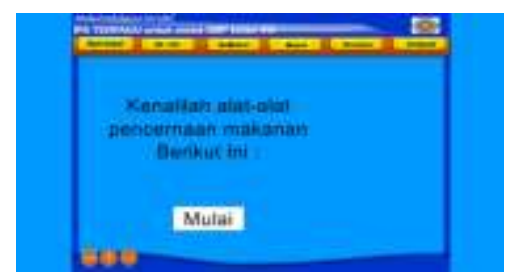

Gambar .2. Tampilan Apersepsi

\section{C.Tampilan SK/KD}

SK atau Standar Kompetensi adalah pernyataan tentang pengetahuan, keterampilan dan sikap yang harus dikuasai siswa serta tingkat penguasaan yang diharapkan dicapai dalam mempelajari suatu mata pelajaran. Sedangkan KD atau Kompetensi Dasar adalah pengetahuan, keterampilan dan kemampuan yang dikuasai oleh seseorang yang telah menjadi bagian dari dirinya, sehingga ia dapat melakukan perilaku kognitif, afektif, dan psikomotorik dengan sebaik-baiknya. SK atau Standar Kompetensi dalam aplikasi ini adalah memahami berbagai sistem dalam kehidupan manusia. Sedangkan KD atau Kompetensi Dasar dalam aplikasi ini adalah mendeskripsikan sistem pencernaan pada manusia dan hubungannya dengan kesehatan.

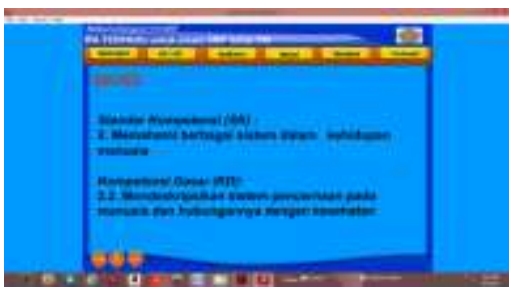

Gambar 3. Tampilan SK/KD

\section{D.Tampilan Materi}

Materi yang dibahas dalam aplikasi ini adalah sistem pencernaan manusia. Sistem pencernaan manusia adalah sistem yang memproses, mengubah makanan dan menyerap sari makanan berupa nutrisi-nutrisi yang dibutuhkan oleh tubuh

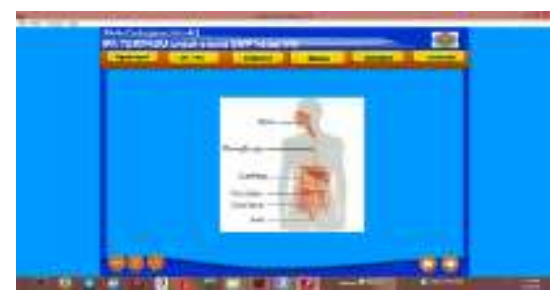

Gambar 4.. Tampilan Materi 1

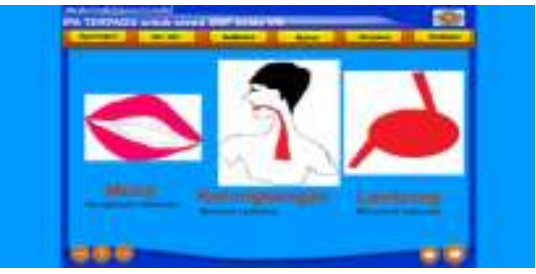

Gambar 5.. Tampilan Materi 2

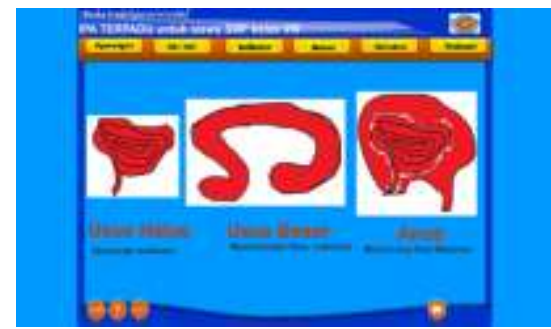

Gambar 5. Tampilan Materi 3

\section{E. Tampilan Simulasi}

Simulasi adalah tampilan berupa video animasi yang berisi penjelasan tentang proses pencernaan manusia. Proses pencernaan manusia terdiri dari empat tahapan proses yaitu menelan, mencerna, menyerap dan membuang.

\section{F.Tampilan Evaluasi}

Evaluasi adalah proses menilai sesuatu berdasarkan tujuan yang telah ditetapkan. Tampilan evaluasi berupa pertanyaan pertanyaan yang harus dijawab oleh siswa untuk mengetahui sejauh mana siswa menguasai materi yang telah dipelajari. Tampilan evaluasi berisi sepuluh pertanyaan dalam bentuk tes objektif. Siswa memilihan jawaban a, b, c, dan d. Apabila menjawab salah siswa disuruh mengulang kembali, sedangkan apabila benar melanjutkan kepada pertanyaan berikutnya.

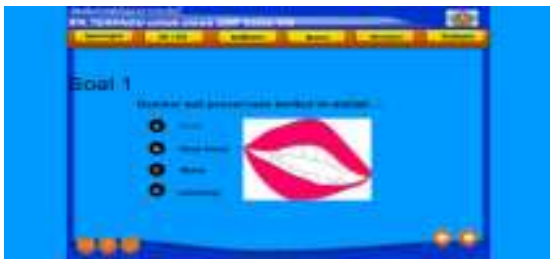

Gambar 1. Tampilan Evaluasi 


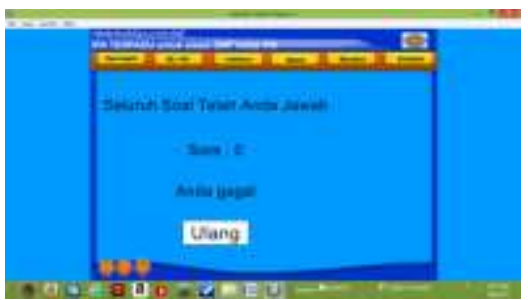

Gambar 2. Tampilan Evaluasi

\section{G. Kelebihan}

Dalam penelitian ini, peneliti dapat menyimpulkan kelebihan dari Multimedia Pembelajaran Interaktif Mata Pelajaran IPA Terpadu untuk Siswa SMPN 5 kota Serang adalah sebagai berikut:

1. Memudahkan siswa menguasai materi pembelajaran tertentu.

2. Meningkatkan daya ingat siswa karena media ini dilengkapi oleh audio, foto dan video sehingga siswa tidak mudah lupa.

3. Menarik perhatian siswa

\section{H. Kekurangan}

Dalam penelitian ini, peneliti dapat menyimpulkan kekurangan dari Multimedia Pembelajaran Interaktif Mata Pelajaran IPA Terpadu untuk Siswa SMPN 5 kota Serang adalah sebagai berikut:

1.Karena keterbatasan waktu pembuatan materi yang disampaikan sangat sederhana tidak mencakup seluruh pokok bahasan.Multimedia Pembelajaran Interaktif ini masih perlu disempurnakan, terutama pembuatan gambar masih sangat sederhana, tampilan masih kurang menarik

\section{KESIMPULAN DAN SARAN}

\section{A. Kesimpulan}

Berdasarkan analisis, pembuatan Media Pembelajaran Interaktif IPA Terpadu untuk Siswa SMPN 5 Kota Serang dengan menggunakan gabungan media foto, audio dan video yang peneliti bahas, dapat diambil kesimpulan sebagai berikut:

1. Terciptanya sebuah media pembelajaran yang dapat membantu siswa dan guru dalam kegiatan proses belajar mengajar yang lebih baik dan menarik sehingga siswa dapat menguasai materi pelajaran yang diajarkan guru dengan mudah.

2. Melalui media pembelajaran ini di dalam proses belajar mengajar siswa bukan lagi sebagai objek pembelajaran, yang hanya mendengarkan materi pelajaran yang disampaikan oleh guru, tetapi sebagai subjek pembelajaran, yang dapat memilih materi yang siswa sukai, dan guru berperan sebagai fasilitator, membantu siswa jika siswa mendapatkan kesulitan.

3. Media pembelajaran interaktif adalah perangkat lunak berisi pesan atau informasi yang terencana dapat merangsang siswa untuk melakukan aktivitas belajar sehingga tercipta lingkungan belajar yang kondusif, efektif dan efisien.memungkinkan bagi siapapun (guru selaku fasilitator dan siswa) untuk senantiasa "explore" dengan memanfaatkan detail-detail di dalam multimedia dalam menunjang kegiatan belajar.

\section{B. Saran}

Dalam pembuatan skripsi ini, ada beberapa saran yang akan menjadi bahan pertimbangan dan pembelajaran bagi peneliti lain yang ingin melanjutkan penelitian ini adalah sebagai berikut:
1. Pada pengembangan berikutnya diharapkan peneliti menambahkan penjelasan yang lebih mendetail pada tampilan materi.

2. Pada tampilan evaluasi hasil tes siswa sebaiknya ditampilkan.

3. Media pembelajaran interaktif ini masih banyak kekurangan yang lainnya sehingga pada pengembangan berikutnya dapat dibuat dan dikemas dengan lebih baik.

\section{DAFTAR PUSTAKA}

Ariani, Niken dan Dani H.2010.Pembelajaran Multimedia di Sekolah. Jakarta:Prestasi Pustaka

Arsyad. 2010. Media Pembelajaran. Jakarta: Raja Grafindo Persada

Abdulhak Ishak.2013. teknologi Pendidikan. Bandung. Remaja Rosda Karya

Daryanto.2010. media Pembelajaran. Jogjakarta. Gava Media.

Deporter, Bobbi, dkk. 2009. Quatum Teaching. Jakarta: Kaifa

Djamarah, Saiful Bahri dan Aswan. 2010. Strategi Belajar Mengajar. Jakarta: Rineka Cipta

Fathurohman, Pupuh dan Sobry .2010. Strategi Belajar Mengajar:Melalui Penanaman Konsep Umum dan Konsep Islami. Bandung: Refika Aditama

Gunawan, Drs. Asep.2015. Buku Induk SMPN 5 Kota Serang. Tidak diterbitkan.

Hamdan, DR, dkk. 2014. Pedoman penulisan Karya Ilmiah. Serang. Unsera

Kinasih, Dwi dan Nugroho Agung Prabowo.2014.Pembuatan Media Pembelajaran Interaktif Sholat Fardu Lima waktu. Speed Jurnal-Sentra Penelitian Engineering dan Edukasi-Volume 11 No 1- Februari 2014 - ijns.org

Maryani, Dwi. 2015. Pembuatan Media Pembelajaran Interaktif Bangun Ruang Matematika. Speed Jurnal - Sentra Penelitian Engineering dan Edukasi - Volume 12 No $1-2015$ - ijns.org.

Munadi. 2008. Media Pembelajaran. Ciputat: Gaung Persada (GP)

Press

Nurhasanah, Youlia Indrawati dan Senyelda. 2011. Implementasi Model Cmifed pada Multimedia Interaktif untuk Pembelajaran Anak Usia TK dan Playgroup. Jurnal Informatika: No.2, Vol.2, Mei - Agustus 2011

Rosari, Renati Winong. 2010. Adobe Flash CS3 untuk Pemula. Jogjakarta. Penerbit Andi.

Rusman, 2010. Model-Model Pembelajaran MengembangkanProfesional Guru. Jakarta:rajawali Pers.

Sadiman, Arief S,dkk.2010. Media Pendidikan:Pengertian, Pengembangan, dan Pemanfaatannya. Jakarta:Rajawali Pers 